\title{
Contradictions to Regulatory Measures and Their Impact on Global and National Agricultural Markets
}

\author{
Frolova E.Yu., Nikonov A.A. \\ All-Russian Scientific Research Institute for Agricultural \\ Economics, \\ Moscow, Russia
}

\author{
Mukhametzyanov R.R., Korol'kov A.F. \\ Moscow Timiryazev Agricultural Academy, \\ Moscow, Russia
}

\author{
Zaretskaya A.S. \\ Yaroslav-the-Wise Novgorod State University, \\ Veliky Novgorod, Russia, \\ Anastasiya.Zaretskaya@novsu.ru
}

\begin{abstract}
The main purpose of this study is to identify contradictions between global, regional and national regulators in the framework of the regulation of the export and import of agricultural raw materials and food. On the one hand, the formation and activity of international economic organizations is aimed at the development of international trade, facilitating the conditions for manufacturers from different countries of the world to access foreign markets. On the other hand, national and supranational (within the framework of integration unions of states) power structures use various restrictions to prevent foreign manufacturers' products from entering local markets, which, for one reason or another, do not comply with the requirements applicable to them. Based on the study of the stated problem, we conducted a critical analysis of various points of view regarding the role and significance of these regulators, as well as their interaction with each other. As practice shows, the regulation of foreign economic trade operations by international economic organizations and unions of states has a great impact on global and national agri-food markets, the volumes and directions of exportimport flows of agricultural products, the state and prospects of food consumption, is the most important part of the foreign and domestic economic country-specific policies. The presence of significant contradictions in the positions of the states of the world regarding the use of various instruments for regulating international trade in agricultural raw materials and food is revealed. The results of the study can be used to further discuss this problem in order to find compromises in the activities of global, regional and national regulators for the regulation of the export and import of agricultural products.
\end{abstract}

Keywords-agricultural products, global and national markets, export, import, regulation, contradictions

\section{INTRODUCTION}

Despite the fact that the agri-food sector of the economy takes an ever smaller share in the creation of the global gross product, its economic, social and political importance in most countries of the world, including developed ones, is not in doubt. Achievements of scientific and technological progress make it possible to create a highly intensive and efficiently functioning agriculture capable of providing not only its own needs in agricultural raw materials and food, but also producing additional volumes of products with which the country can act as an exporter on the global market [1]. At the same time, in the absence or shortage of certain types of agricultural products, they can be purchased from countries that specialize in their production.

The Russian Federation is one of the largest producers of agricultural raw materials and foodstuffs, meeting its demand for basic types of products through its own production. Our country also acts on the world market as a significant exporter (for example, grain) and an importer of a number of types of products (for example, fruits) [2]. Russia has a significant potential for increasing the supply of agricultural products to other countries, but penetration into the markets of foreign countries is difficult due to various kinds of restrictions, which are actively used by many countries of the world, especially developed ones.

International trade in products of plant and animal origin originated during the formation of the first states [3]. At that time and later, the main structures regulating and regulating these processes were merchant guilds, some religious organizations, as well as the authorities of specific countries regarding the stimulation or restriction of export and import 
flows of products, the collection of duties, and trade with dependent territories.

In the modern world, there are various international economic organizations that, within the framework of their powers and areas of activity, are engaged in the regulation and regulation of trade and financial relations at the global (for example, the World Trade Organization), regional (AsiaPacific Economic Cooperation) or sectoral levels (Organization of countries exporters of oil). In addition to them, within the framework of unions or integration groupings of countries (such as the North American Free Trade Agreement, the European Union, the Eurasian Economic Union), general rules for conducting trade operations are being developed, customs tariffs, sanitary standards, etc. are coordinated.

The most authoritative (from the point of view of the member states) among the global regulators of trade and financial relations are the United Nations (UN) - 188 member countries, and the World Bank (WB) - 188 member countries, which are part of its structure, the International Monetary Fund (IMF) - 188 member countries, the World Trade Organization (WTO) - 158 member countries. Their activity is global in nature. As of December 31, 2019, the UN member states, the WB and the IMF formed $99.15 \%$, and the WTO member countries $-91.9 \%$ of the world gross product (in terms of purchasing power parity (PPP) [4].

The rules of trade and financial relations agreed by global international organizations and the current rules are not an obstacle to the establishment of specific regional ties for countries in different parts of the world, most of which currently have membership in various trade and economic unions and integration groups. Among the fairly large ones, they can be noted (as of December 31, 2019, in descending order of total GDP in \% of the world gross product in terms of PPP): AsiaPacific Economic Cooperation (APEC) - 53.58\%; South Asian Association for Regional Cooperation - 51.69\%; Organization for Economic Cooperation and Development (OECD) 42.52\%; BRICS countries - 33.37\%, Shanghai Cooperation Organization (SCO) - 31.64\%; The European Economic Area (EEA) $-16.47 \%$ and the European Union (EU) - $15.78 \%$.

As you know, the World Trade Organization is the successor to the General Agreement on Tariffs and Trade (GATT), concluded in 1947. GATT operated for about 50 years, but did not receive an organizational legal form. With the aim of further liberalization and regulation of trade and political relations in the field of international trade, on January 1, 1995, the WTO was established. Influenced by the Food and Agriculture Organization of the United Nations, from the early 2000s to the present, the WTO has increasingly focused on solving the food problems of developing countries, since achieving "zero" hunger by 2030 is one of the priority goals of sustainable development. Nevertheless, there are opposite views regarding the mechanisms of its achievement. In particular, the countries-leading exporters of agricultural products, as part of the solution to the global food problem, are interested in increasing their supplies to the markets of other states, rather than in developing their own branches of agriculture and food industry in the latter.

This, to a certain extent, fuels a conflict of interest between states adhering to the principles of the "highest" customs and tariff liberalism in international trade in agricultural raw materials and food (USA, Australia, New Zealand and others, including some developing countries), and countries more committed to conducting protectionist policies (in particular the European Union).

The severity of these contradictions affects not only the functioning of the World Trade Organization. In particular, the Transatlantic Trade and Investment Partnership (TTIP), which was planned at one time, was ultimately not created due to significant differences in the positions of representatives of the US agribusiness and similar entities of the European Union. During the discussions, these parties showed serious contradictions in their views on the abolition of many standards and a number of benefits for the production of agricultural raw materials and food.

In addition, the level of state support for their own agri-food sector in economically developed countries of the world is significantly higher, in connection with which some developing countries that are net exporters of agricultural raw materials and food (Brazil, Argentina, South Africa, India, Thailand, etc.) since the time of the Uruguay round of multilateral negotiations have consistently advocated a significant reduction in its volume [5]. As evidence of their position, representatives of these states say that the existing level of domestic support for most OECD countries, together with protectionist tariff barriers, leads to overproduction of agricultural products in them, which ultimately negatively affects the state and trends in the development of production and trade in the world. As a result of the export of surplus products in excess of domestic needs, prices in world markets are falling. In the context of low prices, producers from developing countries find it difficult to compete with exports from OECD countries, not only in international, but also in domestic markets.

At the moment, due to the significant difference in conditions and views, contradictions between the WTO member countries and within other trade and economic unions continue to persist, and in some cases intensify.

The World Trade Organization, by establishing incentives for developing countries, is unable to influence the fact that the existing barriers to access to the markets of the developed countries of the world are virtually insurmountable, and it is almost impossible for most developing countries to withdraw products of deep processing to them. In addition, the WTO initiates discussions, as a result of which the situation for developing countries may become even more difficult. In particular, the United States and some European countries tried to raise the issue of compulsory observance of working conditions when collecting bananas, coffee, etc., which, if accepted, would worsen the competitive position of producers from the states in which these types of products are grown. The refusal of the World Trade Organization from this kind of "leveling" of conditions also leads to conflicts of interest between developed and developing countries. In this regard, politicians and leaders of various countries of the world criticize the position of the WTO, in particular, US President Donald Trump has repeatedly expressed dissatisfaction with the work of this global regulator.

\section{DISCUSSION}

There are several types of instruments to stimulate or restrict the export and import of goods of any group. The main role belongs to customs and tariff and non-tariff regulation. It is 
these instruments that are key within the framework of regional unions and integration groupings of states - in the European Union, in the European Economic Area (EEA), in the European Free Trade Association, in the Eurasian Economic Union (EAEU), in the Asia-Pacific Economic Cooperation (APEC), in the Association of Southeast Asian Nations (ASEAN), in the African Union (AU) and all unions of African countries, in the Agadir Agreement (GAFTA) and other unions of the Middle East countries, in the North American Free Trade Area (NAFTA), Mercosur and others. Within the framework of these trade and economic unions, special conditions are established for the member states [6]. As a rule, duty-free trade is carried out between them and the requirements of customs legislation with respect to other countries are standardized.

In addition, there are non-tariff forms of regulation and regulation, which operate in four areas, the essence of which we will reveal in more detail.

The first area is quantitative import restrictions. This usually includes tools such as automatic licensing - monitoring imports, non-automatic licensing - obtaining prior authorization for sensitive goods and/or requirements for mandatory content of local components, quotas, import bans.

All these tools are used when a threat arises to the national production sector on the basis of Article 2 of the Agreement on Safeguard Measures of the GATT/WTO in relation to the members of the World Trade Organization.

For example, the European Economic Community (EEC), which, along with the United States, was one of the largest importers of bananas in the world, in 1975 signed an international treaty with 48 former colonies (mainly Great Britain and France), according to which these countries were granted a duty-free regime for trade in this fruit on the territory of the EEC. At the same time, supplies of bananas grown in Latin America (countries such as Ecuador, Costa Rica, Guatemala, Panama, etc.) were subject to quotas and were subject to import duties. In addition, a number of other nontariff restrictions were introduced, for example, their import from these countries was licensed [7].

A number of EEC members, in particular Germany, advocated the liberalization of international trade in bananas, but the situation persisted even after the creation of a single European market in 1993. It did not suit either the Latin American states, which are producers and suppliers of this fruit to the world market, or the US transnational corporations. , directly or indirectly controlled about $60 \%$ of banana exports from these countries. Only after several years of litigation both within the framework of the GATT and the World Trade Organization, created in 1995, including through lobbying the interests of its TNCs by the United States, in 2001 the European Union pledged to introduce, from January 1, 2006, for bananas from the Latin America only tariff regime (no import licensing and quotas), as well as significantly reduce the supply quota of this fruit for the former colonies.

Another example is the tariff quota for soft wheat with medium and low protein content, which was introduced in the European Union since 2003. Of the total volume of 3 million tons, 572 thousand tons were intended for the United States of America, and for Canada 40 thousand tons. The remaining amount is intended for all other countries of the world (except for the two North American countries listed above), divided into four equal tranches per quarter of the year. At the same time, the size of the import duty within this quota is equal to 12 euros per 1 ton of wheat. As for the volumes in excess of this quota, in this case the import duty is 95 euros per 1 ton of this type of cereal. Such a high actual size predetermines the situation that there is practically no wheat supply to the European Union outside the quotas. An interesting fact is that for the EAEU countries, some of which, in particular Russia, are large wheat producers, an individual import sub-quota is not provided. [8].

However, as practice shows, developing countries also use import restrictions. In particular, in the late 90 s of the last century, the Indonesian government introduced a series of sanctions on the import of agricultural products in order to improve the situation of food self-sufficiency. A number of WTO members such as the United States and New Zealand have been involved in litigation against that country's policies [9]. Interestingly, Australia, as the largest exporter of agricultural products to Indonesia, which was supposed to be the most severely affected country, joined the WTO dispute resolution procedure not as a plaintiff, but simply as a third party.

The second area is barriers affecting the price of imported goods, which include non-tariff restrictions in the form of administrative fixed prices, anti-dumping measures, additional customs duties, etc. In particular, anti-dumping measures in most of the economically developed countries of the world are a common way of regulating import flows. They are widely used within the framework of the EU's trade policy, and are mainly used in relation to producers from the CIS countries and developing countries.

The third area is technical measures. In particular, in the EU they are applied on the basis of a special regulation of the European Parliament. It provides a number of general principles and requirements for Food Legislation, including covering all stages, from production to distribution of feed and food [10]. In addition to technical standards, the trade policy of the European Union includes a significant list of sanitary and phytosanitary standards. In essence, they are prohibitive in relation to the manufacturer of products of plant and animal origin from countries outside the EU. Thus, the European Union market for agricultural producers from countries that are not part of this integration grouping of states is actually closed by protective measures of a different nature.

Some researchers, based on the study of the impact of European Union food safety standards on those products that are imported into the EU from African countries, indicate that industries heavily dependent on imports are less protected by restrictive measures [11].

The impact of sanitary and phytosanitary (SPS) measures on international trade has been extensively studied in the specialized literature. In particular, we can pay attention to the following scientific work, where it is noted that countries with a higher share of the agricultural sector in the economy or agricultural products in their import use fewer SPS restrictions [12].

Some studies have noted different effects of food standards on the export-import flows of specific products. In particular, it is noted that they can even contribute to an increase in the volume of international trade. This is due to the fact that in some cases, compliance with standards increases demand from some 
countries, as this is influenced by an increase in product quality and increased consumer confidence in its safety. However, standards can distort trade and improve the competitive advantage of those countries that are able to comply with them [13].

A number of researchers note that non-tariff measures that impose a requirement for compliance with certain standards, that is, testing, certification or inspection, reduces the number of countries exporting to the markets of developed countries, such as the USA, Canada, New Zealand, as well as the European Union [14].

Several authors compile a non-tariff measures (NTM) transparency index based on WTO notifications on sanitary, phytosanitary and technical barriers to trade agreements. The resulting rating shows that the OECD countries are generally the most transparent, but the ASEAN countries also perform well compared to other developing countries [15].

In principle, sanitary and phytosanitary measures are aimed at protecting human, plant and animal health, while technical barriers to trade (TBT) ensure product quality and safety. However, national governments can overstate consumer health and safety requirements and use SPS and TBT to protect domestic producers from fair competition from similar entities in other countries. A number of researchers indicate that less developed countries do not receive the same benefits from the implementation of these measures or are at a disadvantage in the export of goods, especially when the importers are advanced economies. In particular, the SPS is more negatively affecting developing countries in Asia, while the exports of non-Asian developing countries are more affected by TBT. Sanitary and phytosanitary measures also damage intraregional trade in agricultural products between Asian countries, which objectively requires politicians to act more actively in resolving non-tariff barriers in the region [16].

Some studies have noted the impact of differences in sanitary and phytosanitary measures on international trade in specific agricultural products, for example, tea [17], fruits [18], meat [19].

The fourth direction is financial measures, which, in particular, include such as: requirements for prepayment; restrictions on payments in foreign currency and its accumulation; regulation of payment terms and other restrictive instruments.

Despite the fact that the role of the World Bank and the International Monetary Fund is, in particular, in the dissemination of the principles of a free market and trade liberalization, since 2010 one can come across assessments of a number of specialists, including former functionaries of these international organizations, about the ill-considered all countries without taking into account the specific conditions in which they are located. As an example, we can cite the situation in Haiti under the influence of the requirements of global regulators with the inability of the governing bodies of this state to take an independent position. Compliance with the conditions of the IMF and WTO on trade liberalization forced the government of the Republic of Haiti to reduce tariffs on imported rice from 50 to $3 \%$, which allowed significant volumes of the grain in question (originating from the United States of America) to enter the market of this country. Ultimately, subsidized US rice displaced Haitian rice, destroying local rice farmers' livelihoods. In 2008, the food crisis hit the population of the Republic of Haiti so hard that riots broke out, forcing the country's president to introduce temporary subsidies on imports of rice, gas and fertilizers. [20]

Practice shows that even within the unions and integration groupings of countries, contradictions may arise, which negatively affect the relevant markets, including agri-food markets. For example, the United States of America and Canada are members of the North American Free Trade Agreement. However, when in July 2018 the US authorities raised tariffs and practically closed their market for steel and aluminum supplies from this friendly state, there was an immediate reaction from Canada. In particular, a list of goods prohibited for import from the United States was announced, including American beef and pork. As a result, under pressure from its agricultural producers, the authorities of the United States of America revised their previous positions in May 2019. Under an agreement signed with the United States, in response to lifting tariffs on steel and aluminum imports, Canada lifted prohibitions on American beef and pork.

The instruments and measures described above for the development of exports, support of national producers and the protection of domestic markets, although they are transformed into special medium and long-term programs, are often sporadic. It should be noted that the role of national regulators has increased significantly since the beginning of the COVID19 pandemic.

\section{CONCLUSIONS}

The study of the practice of regulation, pricing, export support or import restriction by different countries at the state level shows different effects for the actors of the agri-food sector participating in international trade. In particular, measures taken by the governments of a number of states to protect their internal markets can not only seriously affect the position of producers in exporting countries, but also have a negative impact on the efficiency of their activities. For example, Russian suppliers of most animal products cannot enter the market of the EU member states due to a complex system of quality and safety assurance of products imported into their territory, which significantly limits their incentive to increase production volumes.

For our country, which became a full-fledged member of the WTO in 2012, at the present stage, the main role is played by trade and economic interaction within the Eurasian Economic Union (EAEU). Nevertheless, for the Russian Federation, as a state with significant potential for the growth of export-oriented production of agricultural raw materials and food, membership in unions that provide preferential terms of trade is very important, as well as an understanding of the main directions and possible for increasing export volumes. agricultural products of countries [21].

\section{Acknowledgments}

The work is carried out with the financial support of the Russian Foundation for Basic Research under the project 19010-00098. 


\section{References}

[1] N.Ya., Kovalenko, Agricultural Economics: Textbook for Academic Bachelor's Degree [Ekonomika Sel'skogo Khozyaystva: Uchebnik dlya Akademicheskogo Bakalavriata], Moscow: Yurayt Publishing House, 2020. (In Russ.).

[2] Yu.I. Agirbov, "Trends in the import of fruit and berry products in the world and into the Russian Federation" [Tendentsii importa plodovoyagodnoy produktsii v mire i v Rossiyskuyu Federatsiyu], Russian Agricultural Economics, 2020, vol. 3, pp. 97-104.

[3] R.R. Mukhametzyanov, Agricultural markets: methodological origins of teaching and modern practice of analysis: monograph [Sel'skokhozyaystvennyye Rynki: Metodicheskiye Istoki Ucheniya i Sovremennaya Praktika Analiza: Monografiya], Moscow: Publishing house of the RSAU-Moscow Agricultural Academy, 2012. (In Russ.).

[4] EconomicData.ru. (In Russ.). Retrieved from https://www.economicdata.ru/index.php

[5] B.A. Runov, Agrarian policy of the countries of the world: textbook [Agrarnaya Politika Stran Mira: Uchebnoye Posobiye], Moscow Timiryazev Agricultural Academy, 2015. (In Russ.).

[6] Food Outlook. Biannual report on global food markets Food and Agricultural Organization of the United Nations, 2019. Retrieved from http://www.fao.org/3/ca4526en/ca4526en.pdf

[7] A.P. Lesnov, Agricultural markets of the EU and Russia: theoretical and practical aspects (on the example of fruit and vegetable products) Monograph [Sel'skokhozyaystvennyye rynki YES i Rossii: teoreticheskiye i prakticheskiye aspekty (na primere plodoovoshchnoy produktsii). Monografiya], Moscow: MGUP, 2005.

[8] Monitoring, analysis and forecasting of the development of the agroindustrial complex of the EAEU member states. Retrieved from http://www.eurasiancommission.org/ru/act/prom_i_agroprom/dep_agrop $\mathrm{rom} / \mathrm{monitoring}$

[9] D. Ahn, "Indonesia-Import Licensing Regimes: GATT Rules for Agricultural Trade?", World Trade Review, 2019, vol. 18(2), pp. 197-218.

[10] A.F. Korolkov, Regulation of production, processing and trade of organic products in the EU [Regulirovaniye proizvodstva, pererabotki i torgovli organicheskoy produktsii v EU], Russian Agricultural Economics, 2017, vol. 10 , pp. 84-90.

[11] F.O. Kareem, "Indonesia-Import Licensing Regimes: GATT Rules for Agricultural Trade?", International Review of Economics \& Finance, 2018, vol. 53, pp. 185-202.

[12] S. Boza, Sofia, "Factors underlying sanitary and phytosanitary regulation for food and agricultural imports notified by WTO members", Journal of International Trade \& Economic Development, 2017, vol. 26(6), pp. 712723.

[13] H. Medin, "Trade barriers or trade facilitators? The heterogeneous impact of food standards ininternational trade", World Economy, 2019, vol. 42(4), pp. 1057-1076.

[14] M. Webb, Mike, "Market access implications of non-tariff measures: Estimates for four developed country markets“, World Economy, 2019, vol. 42(2), pp. 376-395.

[15] L.Ya. Ing, "Transparency in non-tariff measures: An international comparison", World Economy, 2018, vol. 41(3), pp. 884-912.

[16] J.W. Kang, "Impact of Sanitary and Phytosanitary Measures and Technical Barriers on International”, Trade Journal of World Trade, 2017, vol. 51(4), pp. 539-573.

[17] Ch.W. Hwang, "Effect of non-tariff measures on international tea trades", Journal of Korea Trade, 2017, vol. 21(4), pp. 309-323.

[18] M.-A. Jouanjean, "US phytosanitary restrictions: the forgotten non-tariff barrier", Journal of International Trade Law and Policy, 2016, vol. 15(1), pp. 2-27.

[19] X. Shang, "Sanitary and phytosanitary regulations and international red meat trade", British Food Journal, 2019, vol. 121(10), pp. 2309-2321.

[20] Collections of case studies "Food security in the Eurasian region": 2016, 2017, 2018, and 2019. (In Russ.). Retrieved from https://ecfs.msu.ru/index.php/ru/resources/publications/160-case-studies2016-2017-2018-2019

[21] K.G. Borodin, Export of agricultural products: trends, factors, effects [Eksport Produktsii APK: Tendentsii, Faktory, Effekty], Moscow: A.A. Nikonov All-Russian Institute of Agrarian Problems and Informatics, 2018. (In Russ.). 